\title{
CHEMICAL, CLINICAL, AND IMMUNOLOGICAL STUDIES ON THE PRODUCTS OF HUMAN PLASMA FRACTIONATION. XXVI. THE PROPERTIES OF SOLUTIONS OF HUMAN SERUM ALBUMIN OF LOW SALT CONTENT ${ }^{1,2}$
}

\author{
By G. SCATCHARD, L. E. STRONG, W. L. HUGHES, JR., J. N. ASHWORTH, \\ AND A. H. SPARROW \\ (From the Research Laboratories of Physical Chemistry, Massachusetts Institute of Technology, \\ and Department of Physical Chemistry, Harvard Medical School)
}

(Received for publication May 1, 1945)

Whole plasma is distributed as a dry powder in the interests of preserving its labile constituents. The albumin, the $\gamma$-globulin, the fibrinogen, the thrombin, and most of the other products of plasma fractionation are prepared as dry powders and could also be distributed in the solid state. Separated from each other, purified of the enzymes of plasma, many of them may be distributed, however, as stable concentrated solutions whose specific natural properties, both chemical and biological, remain unaltered for protracted periods of time.

In the fractionation process (1), each of the plasma proteins is precipitated in the neighborhood of its isoelectric point. The dry proteins can be dissolved at any concentration or in any diluent. Since the plasma proteins differ widely in their chemical properties and in their natural functions, the best diluent for each depends both upon these properties and upon the clinical uses for which the solution is prepared.

Solutions intended for clinical use should generally have a $\mathrm{pH}$ not too far from that of the blood; a viscosity not much greater than that of blood; an essentially isotonic concentration of solute molecules, which should, moreover, be chosen so as to enhance to any necessary level the stability of the dissolved proteins. Neutral isotonic sodium chloride has been found less effective in increasing the thermal stability of purified plasma proteins than certain other diluents. Thus

1 This work has been carried out under contract, recommended by the Committee on Medical Research, between the Office of Scientific Research and Development and Harvard University.

2 This is paper No. 36 in the series, "Studies on Plasma Proteins," from Harvard Medical School, Boston, Massachusetts, on products developed by the Department of Physical Chemistry from blood collected by the American Red Cross. the stability of the $\gamma$-globulins is not greatly influenced by sodium chloride but is increased by sugars, by glycine, and by certain other nonelectrolytes. Glycine has been adopted as the diluent in which $\gamma$-globulin is now distributed to the Armed Forces and to the American Red Cross because it gives a sufficient stability, because it is not toxic, and because it is not a foreign substance, but is a native constituent of the body. Although $\gamma$-globulin solutions are more stable in higher concentrations of glycine, ${ }^{3}$ a 0.3 molal solution has been chosen, since it is isotonic and, therefore, more satisfactory for injection.

Human serum albumin was developed as a blood derivative for the treatment of shock. The molecules of this plasma protein are large enough to be held in the blood stream but small enough to have a high osmotic efficiency, ${ }^{4}$ and are so symmetrical that a 25 per cent solution is isoviscous with blood and so stable that it may be dispensed in aqueous solution.

The first normal human serum albumin pro-

3 It may prove unnecessary to stabilize $\gamma$-globulin sufficiently to permit a high temperature treatment for the destruction of viruses since antibodies against the virus of infectious hepatitis have been shown to be present in $\gamma$ globulins from large pools of plasma in sufficient quantities to give protection against the disease (2). Moreover, such a treatment could not be recommended without proof that bacteria and viruses are less stable to heat than the antibodies.

4 Osmotic pressure is used in its classical sense to designate the equilibrium pressure across a membrane with about the same permeability as the capillary walls (3). This is sometimes called the oncotic, or colloid osmotic, pressure. The osmotic efficiency of a material is proportional to the volume of solution at the osmotic pressure of plasma which is produced by unit weight of that material. Osmotically equivalent quantities of two materials are those quantities which produce the same volume of solution at the osmotic pressure of plasma. 
duced by the Harvard Plasma Fractionation Laboratory was a 25 per cent solution of nearly isoelectric albumin in water (4). This concentration was chosen to give the smallest possible volume for transport without increasing the viscosity so much as to render inconvenient the passage through bacteriological filters or injection through an intravenous needle. Very soon, however, the $\mathrm{pH}$ was adjusted to approximate neutrality in order to meet the objections to the infusion of an acid solution, and 0.15 mole sodium chloride per liter was added to render the solution isotonic. ${ }^{5}$ As in the case of plasma, merthiolate or a similar mercurial bacteriostatic agent was introduced at the request of the National Institute of Health when distribution for the Armed Forces began. Later, the sodium chloride content was increased to 0.3 mole per liter (6) in order to render a product distributed in solution more stable at high temperature such as might be expected to be encountered under some military conditions.

The use of normal human serum albumin as a diuretic agent (7) has led to a need for a preparation which contains no mercury and but little sodium ion. Solutions of isoelectric albumin without other added solute have been prepared for experimental studies (8 to 10). Such solutions are strongly hypotonic and hemolyze red cells if injected rapidly without the addition of glucose or other solute to reduce hypotonicity. Such solutions are also acid and unstable. If it were important to inject sodium-free serum albumin, it could be prepared and distributed, as is plasma, as a sterile dry powder with sufficient glucose or other appropriate solute to render the reconstituted solution isotonic, or the isotonic glucose could be distributed in the diluent container. In either case, the package would occupy more than twice the volume of the present container, the solution would still be acid, and the advantage of distributing a stable solution would be lost.

Experimental studies have thus far failed to demonstrate any great advantage in an albumin

5 The tonicity of a solution is most conveniently measured as the ratio of its freezing point depression to that of plasma, $0.56^{\circ} \mathrm{C}$. (5). Thus a solution with freezing point depression less than $0.56^{\circ} \mathrm{C}$. is hypotonic; one with a greater depression is hypertonic. The tonicity depends upon all the solute molecules, and not upon the colloids alone. solution from which the last traces of sodium have been removed. Indeed, the amount of sodium required to neutralize albumin, and thus to avoid injection of an acid solution, is small in comparison to the total sodium intake of a patient on a salt-poor diet (8). Such albumin solutions, neutralized with sodium bicarbonate, and in certain studies rendered isotonic with glucose, have also been prepared. They are far more stable than the isoelectric albumin solutions but less stable than the standard albumin solutions first developed for the Navy. Such salt-poor neutral sodium $^{6}$ albuminate solutions are also far less hypotonic than the isoelectric albumin though far lower in sodium ion than the present standard albumin solution and lower still than the osmotically equivalent volume of plasma.

One hundred $\mathrm{ml}$. of 25 per cent normal human serum albumin is osmotically equivalent to 450 ml. of plasma. This quantity of plasma contains about 1.6 grams of sodium ion. ${ }^{7}$ The present standard albumin solution, which is 0.3 molal in sodium chloride, contains far less sodium ion, 0.9 gram per $100 \mathrm{ml}$., and of this amount only 0.1 gram is required to neutralize the albumin. A further 0.1 gram is required to neutralize the other acids, mostly acetic, which are carried down with the isoelectric albumin precipitate. The latter quantity could be largely eliminated by a further purification of albumin carried out during processing. However, this quantity is small in comparison with the 0.7 gram of sodium ions added to increase the thermal stability of albumin solutions to the present high standard. This amount of sodium ion can be greatly reduced by replacing sodium chloride with other reagents which would satisfy the conditions of thermal stability and tonicity at much lower sodium concentrations.

\section{THERMAL STABILITY OF ALBUMIN SOLUTIONS}

The profound influence of salts of non-polar anions in increasing the thermal stability of serum

6 It is possible that a stable, neutral, sodium-free solution might be obtained by substituting some other cation for the sodium ion, but no more desirable cation has yet been suggested.

7 The osmotically equivalent quantity of the present citrated plasma contains an additional 0.5 gram of sodium ion from the added sodium citrate, making the total sodium about 2.1 grams. 
albumin has been beautifully demonstrated by Luck and his co-workers $(11,12)$. In the aliphatic series, this influence increases with the length of the paraffin chain, being greater for butyrate than for acetate and far greater for caprylate. Other non-polar anions, such as phenylacetate and mandelate, have been shown to be at least as satisfactory as the lower members of the aliphatic series. We have also found that sodium hippurate and other non-polar ions have a similar stabilizing action.

The replacement of 0.3 molal sodium chloride with 0.04 or 0.05 molal sodium phenylacetate or mandelate increases from 4 to 10 times the length of time during which serum albumin can be subjected to high temperatures. Moreover, this substitution reduces to one-sixth or one-seventh the amount of sodium employed in increasing the thermal stability of the protein.

The structural similarity of phenylacetic and mandelic acids to acetylphenylalanine, a simple derivative of a natural amino acid, was pointed out, $^{8}$ and it was suggested that the sodium salt of this acid might also have an influence on the thermal stability of serum albumin. This suggestion has been tested by experiment and confirmed. Substitution for acetylphenylalanine of the acetyl derivative of an amino acid in which albumin is deficient for nutrition was suggested by one of us (13). Crystallized human serum albumin contains but 0.19 per cent tryptophane (14) and must be supplemented by both tryptophane and isoleucine to give satisfactory growth when fed to young rats (15 to 17). Whole plasma also is deficient in isoleucine though not in tryptophane (18).

There are thus a large number of non-polar anions that are effective stabilizing agents for serum albumin solutions. Butyric acid and the next members of this series have strong odors. Phenylacetate and caprylate are more toxic than the others ${ }^{\theta}$ though none of these substances appears to be toxic except when injected in large

8 We are indebted to Dr. Hans T. Clarke for this suggestion, made at a meeting of the Protein Committee of the National Research Council.

9 Studies on toxicity of these reagents that have been carried out by Dr. J. Murray Luck and his co-workers and also by Dr. Otto Krayer are continuing, and final amounts. Sodium mandelate, acetylphenylalaninate and acetyltryptophanate are reported not to differ markedly from each other from the point of view of toxicity or of stability. Sodium mandelate and d-acetyltryptophanate are presumably excreted, whereas 1-acetyl tryptophanate appears on the basis of the evidence thus far available (15, 19) to be utilized by the animal body. These are the non-polar anions which have thus far been used in the most extensive experiments in man (8).

Various methods have been used to follow the influence of reagents on the thermal stability of albumin solutions. ${ }^{10}$ The ultracentrifuge is used to determine the absence of any appreciable amount of aggregation into larger protein complexes or decomposition into elements of smaller molecular weight (20). Aggregation and decomposition, if they involve a large proportion of the dissolved molecules, are also reflected by changes in osmotic pressure (3). Incipient denaturation in these solutions, however, has generally been accompanied by an aggregation of too small a number of molecules to be noted by these methods. It is, however, readily observed by changes of viscosity or by the appearance of haze in the solutions, and can be most conveniently measured in a nephelometer (6). The clarity of albumin solutions after passage through appropriate bacteriological filters has generally been about 10 nephelometric units. ${ }^{11}$ An increase of 20 nephelometric units brings these solutions to the range in which haze is barely perceptible to the eye. The haze is much less than that in reconstituted plasma, and there is no evidence that it is in any way harmful in either case, especially since there is a filter in each transfusion line to remove any large particles.

judgment regarding the usefulness of caprylic acid will be postponed until their completion. These results will be reported elsewhere.

${ }^{10}$ In the case of $\gamma$-globulins, the limiting factor is of course not the stability of the molecule, but of the configuration upon which antibody titer depends. In the case of prothrombin and thrombin, and of the various hormones and enzymes of plasma, the stability of the active principle must be considered, as well as that of the protein molecule.

11 The unit adopted in these measurements is approximately 1 per cent of the turbidity of a standard whose absolute turbidity is given as $\mathbf{0 . 0 1 9 3}$. 
However, haze may be employed as a quantitative measure of incipient protein denaturation.

The further aggregation of protein leads in time to the appearance of a gel in the solution. The relation between the number of days required for an increase of 20 nephelometric units as a result of heating at $57^{\circ} \mathrm{C}$. to that required for incipient gelation at this temperature is graphically represented for 150 preparations of normal human serum albumin in a previous communication (6). On the average it took about 3 times as long to observe incipient gelation as to observe nephelometrically the first visible haze.

The measurements that have now been carried out in order to determine the influence of various stabilizing agents are presented in Tables I, II and III. The methods were the same as those used previously (6) but with standard human serum albumin (1) instead of crystallized albumin. The stabilizing agent was added as the sodium salt to prevent denaturation of the albumin. The albumin was neutralized with $\mathrm{NaHCO}_{3}$ except in the solutions described in Table II and in the rast column of Table III, Albumin B. All solutions were filtered through asbestos sterilizing filter pads (Seitz, serum No. 3). Studies were carried out at $57^{\circ} \mathrm{C}$., $60^{\circ} \mathrm{C}$., and $63^{\circ} \mathrm{C}$., and the times necessary for the increase of 20 nephelometric units and for gelation are both recorded. Gelation seems to be less affected than turbidity by the very active stabilizing agents, and the ratio of times decreases from three to almost unity for the extremely stable solutions.

In dilute solutions of the diluents, it is shown in Table I that the stabilizing action increases more rapidly than the reagent concentration. In higher concentrations, however, the stabilizing effect approaches a limiting value. The effects of sodium acetyltryptophanate and of mandelate are nearly the same, the stability in 0.04 molal solution being 2 or 3 times that in 0.3 molal sodium chloride. Sodium caprylate has a somewhat larger effect in 0.01 molal and a much larger effect at higher concentrations.

By either method of estimating incipient denaturation, the $\mathrm{pH}$ of optimum stability at these temperatures and in the diluents now reported appears from Table II to be at reactions close to neutrality. In the presence of these diluents and at these temperatures, the $\mathrm{pH}$ range previously specified, $6.8 \pm 0.2$, still appears to be the optimum.

TABLE I

Effect of stabilizer concentration on stability

\begin{tabular}{|c|c|c|c|c|c|c|c|c|}
\hline \multirow{3}{*}{ Reagent } & \multirow{3}{*}{$\mathrm{pH}$} & \multirow{3}{*}{$\begin{array}{c}\text { Method of measuring } \\
\text { denaturation }\end{array}$} & \multicolumn{6}{|c|}{ Moles of reagent per liter } \\
\hline & & & 0.01 & 0.02 & 0.03 & 0.04 & 0.08 & 0.3 \\
\hline & & & \multicolumn{6}{|c|}{ time in hours at $57^{\circ} \mathrm{C}$. } \\
\hline
\end{tabular}

Albumin A

\begin{tabular}{l|l|l|l|l|l|l|l}
\hline Sodium chloride & 6.8 & Nephelometry & & & & & \\
Sodium acetyltryptophane & 6.65 & Nephelometry & 24 & 68 & 120 & 225 & \\
Sodium mandelate & 6.8 & Nephelometry & 25 & 71 & 120 & 215 & \\
Sodium caprylate & 6.65 & Nephelometry & 40 & 480 & & & \\
\hline
\end{tabular}

Albumin C

\begin{tabular}{|c|c|c|c|c|c|c|c|}
\hline 'Sodium chloride & 6.8 & Nephelometry^ & & & & & 38 \\
\hline Sodium acetyltryptophane & 6.8 & $\begin{array}{l}\text { Gelation } \\
\text { Nephelometry }\end{array}$ & $\begin{array}{l}70 \\
19\end{array}$ & $\begin{array}{r}120 \\
40\end{array}$ & $\begin{array}{l}390 \\
180\end{array}$ & $\begin{array}{l}520 \\
430\end{array}$ & \\
\hline Sodium mandelate & 6.8 & $\begin{array}{l}\text { Gelation } \\
\text { Nephelometry* }\end{array}$ & $\begin{array}{l}34 \\
11\end{array}$ & $\begin{array}{r}120 \\
35\end{array}$ & $\begin{array}{l}290 \\
129\end{array}$ & $\begin{array}{l}670 \\
450\end{array}$ & \\
\hline Sodium caprylate & 6.8 & $\begin{array}{l}\text { Gelation } \\
\text { Nephelometry }\end{array}$ & $\begin{array}{r}220 \\
70\end{array}$ & $\begin{array}{l}820 \\
470\end{array}$ & $\begin{array}{l}1400 \\
1300\end{array}$ & $\begin{array}{l}2400 \\
2100\end{array}$ & \\
\hline
\end{tabular}

- Time in hours to increase 20 nephelometric units. 
TABLE II

Effect of hydrogen ion concentration on stability of human serum albumin

A. Solutions containing 0.04 mole sodium acetyltryptophanate and 0.1 mole isoleucine

\begin{tabular}{|c|c|c|c|c|c|c|}
\hline \multirow{3}{*}{$\begin{array}{l}\text { Tem- } \\
\text { pera- } \\
\text { ture }\end{array}$} & \multirow{3}{*}{$\begin{array}{c}\text { Method of meas- } \\
\text { uring denaturation }\end{array}$} & \multicolumn{5}{|c|}{$\mathrm{pH}$} \\
\hline & & 6.6 & 6.8 & 7.0 & 7.2 & 7.5 \\
\hline & & \multicolumn{5}{|c|}{ time in hours } \\
\hline $57^{\circ} \mathrm{C}$. & $\begin{array}{l}\text { Gelation } \\
\text { Nephelometry }\end{array}$ & $\begin{array}{l}350 \\
106\end{array}$ & $\begin{array}{l}350 \\
122\end{array}$ & $\begin{array}{l}350 \\
146\end{array}$ & $\begin{array}{l}320 \\
164\end{array}$ & $\begin{array}{l}290 \\
142\end{array}$ \\
\hline $60^{\circ} \mathrm{C}$. & $\begin{array}{l}\text { Gelation } \\
\text { Nephelometry }\end{array}$ & $\begin{array}{l}80 \\
24\end{array}$ & $\begin{array}{l}80 \\
27\end{array}$ & $\begin{array}{l}80 \\
32\end{array}$ & $\begin{array}{l}70 \\
30\end{array}$ & $\begin{array}{l}50 \\
22\end{array}$ \\
\hline \multirow[t]{2}{*}{$63^{\circ} \mathrm{C}$. } & $\begin{array}{l}\text { Gelation } \\
\text { Nephelometry }\end{array}$ & $\begin{array}{c}12 \\
3.2\end{array}$ & $\begin{array}{l}12 \\
3.4\end{array}$ & $\begin{array}{c}12 \\
3.4\end{array}$ & $\begin{array}{l}10 \\
3.3\end{array}$ & $\begin{array}{l}7.5 \\
2.2\end{array}$ \\
\hline & & \multicolumn{5}{|c|}{ time in hours after 10 hours at $60^{\circ} \mathrm{C}$. } \\
\hline $57^{\circ} \mathrm{C}$. & $\begin{array}{l}\text { Gelation } \\
\text { Nephelometry } \\
\text { Nephelometry }^{\mathrm{a}}\end{array}$ & $\begin{array}{r}300 \\
94 \\
72\end{array}$ & $\begin{array}{r}300 \\
84 \\
70\end{array}$ & $\begin{array}{r}300 \\
123 \\
96\end{array}$ & $\begin{array}{r}280 \\
110 \\
96\end{array}$ & $\begin{array}{l}76 \\
64\end{array}$ \\
\hline
\end{tabular}

B. Solutions containing $\mathbf{0 . 0 4}$ mole sodium acetyltryptophanate

\begin{tabular}{|c|c|c|c|c|c|c|}
\hline \multirow[b]{4}{*}{$57^{\circ} \mathrm{C}$. } & \multirow[b]{4}{*}{$\begin{array}{l}\text { Gelation } \\
\text { Nephelometry } \\
\text { Nephelometry }\end{array}$} & \multicolumn{5}{|c|}{ pH } \\
\hline & & 6.3 & 6.9 & 7.3 & 7.6 & \\
\hline & & \multicolumn{5}{|c|}{ time in hours after 10 hours at $60^{\circ} \mathrm{C}$. } \\
\hline & & $\begin{array}{r}340 \\
27 \\
18\end{array}$ & $\begin{array}{r}350 \\
107 \\
89\end{array}$ & $\begin{array}{l}320 \\
120 \\
110\end{array}$ & $\begin{array}{r}220 \\
57 \\
48\end{array}$ & \\
\hline
\end{tabular}

- Hours to increase turbidity by 20 nephelometric units. b Hours to increase turbidity to value 20 nephelometric units above that before heating at $60^{\circ} \mathrm{C}$.

These results may also be employed in calculating the average temperature coefficient of stability. The length of time that albumin solutions maintain the same stability at these temperatures is approximately halved by each increase of $1^{\circ} \mathrm{C}$. The average temperature coefficients vary from 1.6 to 1.9 for the range $57^{\circ} \mathrm{C}$. to $60^{\circ} \mathrm{C}$. and from 2.0 to 2.2 for the range from $60^{\circ} \mathrm{C}$. to $63^{\circ} \mathrm{C}$. The temperature coefficient appears to increase slightly with increase in temperature and also with increase in alkalinity.

\section{HEAT TREATMENT OF HUMAN SERUM ALBUMIN IN FINAL CONTAINERS}

For a long time there has been a search for some substitute for mercurial bacteriostatic agents in plasma and in albumin solutions. Not only do they appear to be much less effective in concentrated protein solutions than in many other media, but also a limiting factor in the amount of albumin, as of plasma, that can be safely injected in certain conditions may become the toxicity of the mercurial added as a preservative. A heat treatment similar to pasteurization seems to offer a simple way of eliminating to a considerable degree the necessity of a mercurial. It has the further advantage of destroying viruses, which might be present, as well as bacteria. ${ }^{12}$

There is very little information upon which to determine the heat treatment necessary to destroy bacteria or. viruses. Preliminary experiments ${ }^{13}$. indicate that vaccinia virus is completely destroyed in 1 hour at $57^{\circ} \mathrm{C}$. or 3.5 minutes at $68^{\circ} \mathrm{C}$. in the presence of sodium mandelate and probably in the presence of sodium phenylacetate. Some results $(21,22)$ indicate, however, that the activity of tobacco mosaic virus is destroyed much more slowly. The rate of destruction is approximately doubled for each degree rise in temperature, just as for the denaturation of human serum albumin. We have studied the effect on the $57^{\circ}$ stability of heating 10 hours at $60^{\circ} \mathrm{C}$. albumin solutions with 0.04 molal sodium acetyltryptophanate or 0.04 molal sodium mandelate as stabilizing agents, and the results are shown in Tables II and III. As measured by either method, the stabilities are still greater than that of the same albumin with 0.3 molal sodium chloride as diluent. The albumin sample which we have studied most thoroughly may be heated 17 hours at $60^{\circ} \mathrm{C}$. with 0.04 molal sodium acetyltryptophanate before its stability is reduced to that with 0.3 molal sodium chloride. It may be found that for the destruction of some viruses or bacteria, it is desirable to heat for a shorter time at a higher

12 An alternative method for the destruction of viruses and bacteria might be the addition of formalin to the final albumin solution, which also increases the thermal stability. Experiments with 25 per cent solutions of crystallized bovine albumin have shown that concentrations up to 0.6 per cent do not change the immunological properties, as judged by serological tests and the sensitization of guinea pigs, or greatly alter the physical chemical properties.

$13 \mathrm{We}$ are indebted to Dr. John F. Enders for the personal communication of these results. 
TABLE III

Effect of various salts on stability of normal human serum albumin

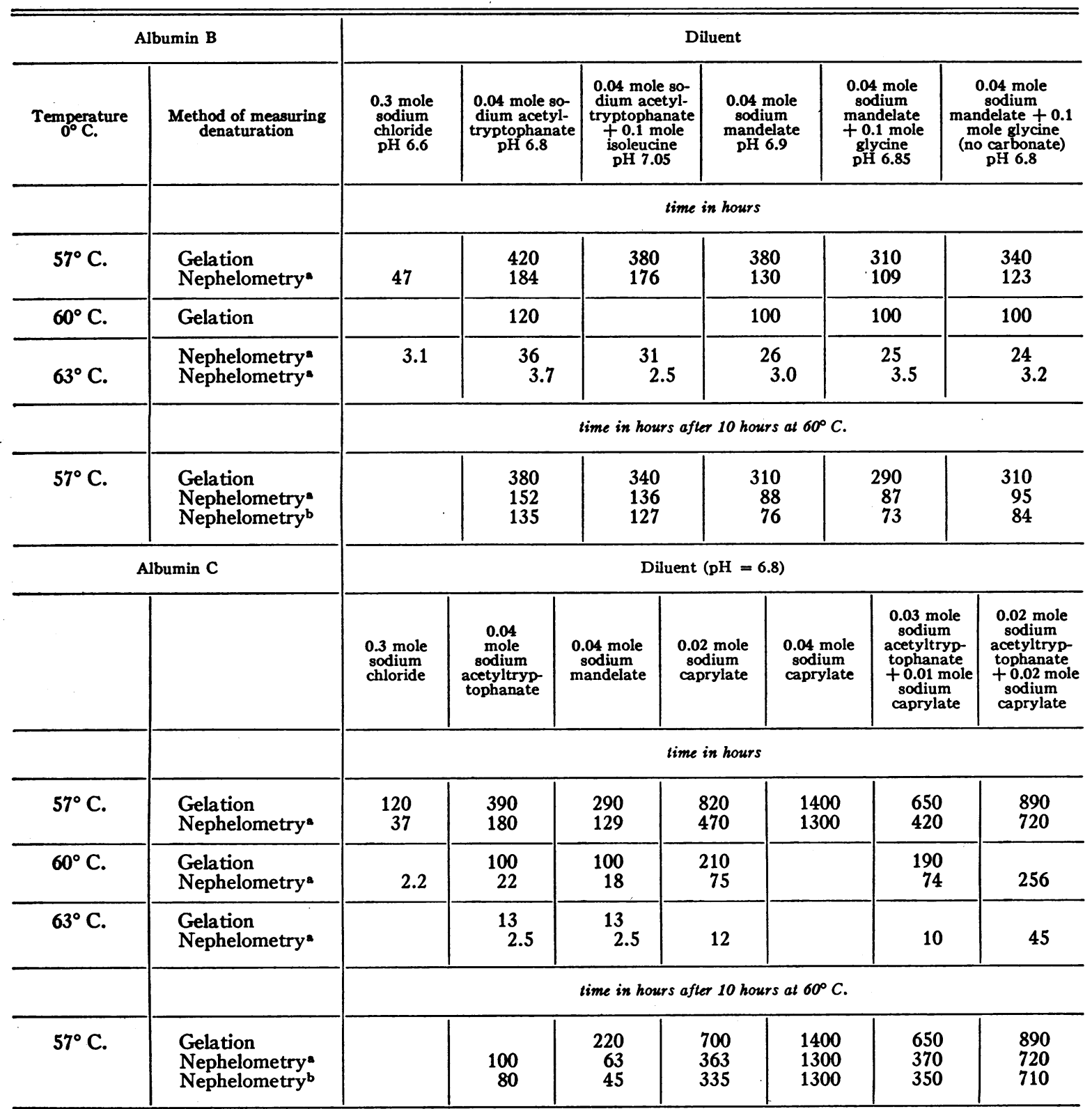

- Hours to increase turbidity by 20 nephelometric units.

b Hours to increase turbidity to value 20 nephelometric units above that before heating at $60^{\circ} \mathrm{C}$.

temperature. Ten hours at $60^{\circ} \mathrm{C}$. are equivalent to 5.5 hours at $61^{\circ} \mathrm{C}$., 2.8 hours at $62^{\circ} \mathrm{C}$., or 1.3 hours at $63^{\circ} \mathrm{C}$. For the destruction of sporulating organisms, it may be desirable to divide the high temperature treatment into 2 parts separated by a period of incubation at $37^{\circ} \mathrm{C}$. The effect upon the albumin will depend upon the total time of heating.
If it should become desirable to give a more vigorous heat treatment in order to destroy some viruses or bacteria, it will be possible to make the albumin more stable at the cost of a somewhat higher sodium content by increasing the concentration of stabilizing agent. The limiting factor will presumably be the toxicity, and it will probably be more efficient to use a mixture of reagents 
which will be eliminated by the body in different ways. It is probable that a little caprylate added to the sodium acetyltryptophanate will be very useful if extreme stability becomes important.

From Table III, it is evident that a mixture of 0.02 molal acetyltryptophanate and 0.02 molal caprylate gives a greater stability at $63^{\circ} \mathrm{C}$. than does 0.04 molal acetyltryptophanate at $60^{\circ} \mathrm{C}$. The sodium ion concentration is the same, and the tryptophane is sufficient to make the albumin complete for growth in rats (15 to 17). It should be practicable to heat this solution 10 hours at $64^{\circ} \mathrm{C}$.

\section{TONICITY OF ALBUMIN SOLUTIONS}

The 25 per cent albumin solution containing 0.3 molal sodium chloride is very hypertonic. Its freezing point depression is about 3 times that of plasma although the ratio of total solutes to osmotically active solutes is only half that of plasma because of its very high concentration. The low salt albumins, on the other hand, are distinctly hypotonic. That containing 0.3 gram per cent sodium has a freezing point depression threequarters that of plasma, and removal of the acetate may be expected to reduce the depression to half that of plasma. The isoelectric albumin with water as diluent is extremely hypotonic. Table IV shows the sodium content, and the freezing point depression of several albumin preparations, as well as their effect on human red blood cells. Only the isoelectric albumin solutions lake the cells.

The addition of d,l-isoleucine at a concentration of 0.1 molal to 25 per cent albumin containing 0.04 molal acetyltryptophanate is reported to make the solution complete for growth in young rats (15.to 17 ), and will increase the freezing point depression to 0.9 to 1.2 times that of plasma without change in the sodium content or in the stability of the albumin. The use of such a diluent has the further advantage that the alkali necessary to neutralize the albumin and the absorbed acids can be added as a buffer mixture of sodium isoleucinate and isoleucine together with the sodium acetyltryptophanate. This makes unnecessary the use of sodium bicarbonate to prevent excessive local alkalinity during the neutralization and eliminates the possibility of a shift in $\mathrm{pH}$ due to loss of carbon dioxide. The stabilities of such solutions are presented in Table II. These advantages, other than the possible nutritional value, can also be obtained from glycine.

\section{THE NEW STANDARD ALBUMIN SOLUTION}

There is a great advantage in having an albumin solution which either can be infused alone or can be used combined with any appropriate diluent

TABLE IV

Sodium content and tonicity of albumin solutions

\begin{tabular}{|c|c|c|c|c|c|c|c|c|}
\hline \multirow[t]{2}{*}{ Albumin type } & \multirow[t]{2}{*}{ Diluent } & \multirow[t]{2}{*}{ Number } & \multirow[t]{2}{*}{$\mathrm{pH}$} & \multirow{2}{*}{$\begin{array}{c}\text { Sodium } \\
\begin{array}{c}\text { grams } \\
\text { per cent: }\end{array}\end{array}$} & \multirow[t]{2}{*}{$\begin{array}{l}\text { Freezing } \\
\text { point "de- } \\
\text { pression }\end{array}$} & \multicolumn{3}{|c|}{$\begin{array}{l}\text { Percentage change in volume of packed } \\
\text { red cells }\end{array}$} \\
\hline & & & & & & I & II & III \\
\hline Standard & 0.3 mole $\mathrm{NaCl}$ & 93R & 6.8 & 0.97 & 1.76 & -17 & -24 & -32 \\
\hline $\begin{array}{l}\text { Standard } \\
\text { Low salt }\end{array}$ & $\begin{array}{l}0.3 \mathrm{~mole} \mathrm{NaCl} \\
0.04 \text { mole sodium }\end{array}$ & $\begin{array}{l}97 R_{2} \\
153\end{array}$ & 7.3 & 0.32 & 0.47 & +19 & $\begin{array}{l}-18 \\
+21\end{array}$ & $\begin{array}{l}-22 \\
+11\end{array}$ \\
\hline Low salt & 0.04 mole sodium & 158 & 7.0 & 0.29 & 0.42 & +29 & +29 & +18 \\
\hline Low salt & $\begin{array}{l}\text { acetyl tryptophanate } \\
0.04 \text { mole sodium }\end{array}$ & $158 \mathrm{H}^{\mathrm{d}}$ & 7.0 & 0.29 & 0.42 & +27 & +26 & +16 \\
\hline Salt-free & $\begin{array}{l}\text { acetyl tryptophanate } \\
\text { none }\end{array}$ & 149 & 4.8 & 0.00 & 0.08 & laked & laked & laked \\
\hline
\end{tabular}

- Measurements made by Miss K. Fahey in the laboratory of Dr. James L. Gamble, Children's Hospital, Boston.

b Measurements made by Dr. Alexander Brown and Miss J. Weeks. The freezing point depression of plasma is $0.56^{\circ} \mathrm{C}$. (5).

- Measurements made by Dr. Frank L. Plachte in the laboratory of Dr. Charles A. Janeway, Children's Hospital, Boston: $2 \mathrm{ml}$. of heparinized blood mixed with $2 \mathrm{ml}$. of 25 per cent albumin solution; incubated at $37^{\circ} \mathrm{C}$. for $1 \mathrm{hour}$; centrifuged for 2 hours at 2500 RPM; supernatant plasma examined for hemolysis. Control tubes contained 2 ml. of heparinized blood mixed with $2 \mathrm{ml}$. of the donor's plasma. Determinations were made with three different bloods, I, II and III.

d 158 heated ten hours at $60^{\circ} \mathrm{C}$. 
for a particular therapeutic use. Such combination was foreseen at an early date, and the standard Army-Navy' double-ended bottle was designed ${ }^{14}$ to permit the intravenous administration of saline, glucose, or other solution with the albumin. It has sometimes been found even more convenient in the field to mix 2 fluids by inserting the needle attached to the container of 1 solution into the rubber tube through which the other is being injected.15 Sufficient saline or glucose may readily be added so that the average albumin concentration is isosmotic with plasma or even more dilute. This may be desirable in severe shock or in marked dehydration. If it is desired to administer a large amount of base, it can be added as an isotonic solution of sodium lactate or other similar salt. Although it is possible to increase the ratio of sodium to albumin to any extent by simultaneous injection, it is not possible to decrease it in this way below the ratio in the original albumin solution, and a low ratio appears desirable if the albumin is to be used as a diuretic. A solution of 25 per cent albumin at $\mathrm{pH} 6.8$ with 0.04 molal sodium acetyltryptophanate and 0.1 molal isoleucine if indicated, ${ }^{16}$ without a mercurial bacteriostatic agent, but pasteurized 10 hours at $60^{\circ} \mathrm{C}$. or an equivalent time at some other temperature, has therefore been recommended, not only as a diuretic agent, but also to replace for use in shock the sodium chloride containing albumin heretofore available. On the basis of the accumulated chemical and clinical evidence, the Navy is now procuring albumin according to these specifications.

\section{SUMMARY}

(1) Normal human serum albumin, like other products of plasma fractionation, is separated near its isoelectric point and prepared as a dry white powder. It can, therefore, be redissolved at any concentration and distributed in any diluent.

\footnotetext{
14 The package adopted by the Armed Forces for the standard 25 per cent albumin solution was developed by Captain Lloyd R. Newhouser, Medical Corps, United States Navy and Lt. Col. Douglas Kendrick, Medical Corps, United States Army.

15 This method has been of greatest utility in the supplementing of whole blood infusions with concentrated albumin solutions.

16 The heat treatment may possibly alter the nutritional value of the albumin.
}

(2) The 25 per cent neutral solution that has been made available to the Armed Forces has the advantage of small volume, high osmotic efficiency, low viscosity and high thermal stability. No changes have been suggested to improve its safety and effectiveness for use in shock.

(3) Use of normal human serum albumin as a diuretic agent has led to the development of a preparation which contains no mercurial preservative and but very little sodium. The clinical studies on the use of such preparations in shock, as well as in other conditions, are reported elsewhere.

(4) One hundred $\mathrm{ml}$. of 25 per cent normal human serum albumin neutralized to $\mathrm{pH} 6.8$ contains 0.2 gram of sodium. It is osmotically equivalent to $450 \mathrm{ml}$. of plasma which contains 1.6 grams of sodium or to $500 \mathrm{ml}$. of citrated plasma which contains 2.1 grams. Further reduction in the sodium content of standard neutral albumin preparations could be effected since but 0.1 gram is bound by the albumin and 0.1 gram is present as sodium acetate and citrate.

(5) The addition of 0.1 gram of sodium as the salt of a non-polar anion, such as acetyltryptophanate or mandelate $(0.04$ molal $)$, is sufficient to render the albumin more stable than in previous preparations which contained 3 times as much sodium.

(6) Acetyltryptophane in this amount is sufficient to supplement the albumin with respect to the amino acid in which it is most deficient. Addition of 0.1 molal isoleucine, in which plasma as a whole is also deficient, renders albumin adequate for the growth of rats.

(7) The standard albumin with 0.04 molal salt is moderately hypotonic. The addition of 0.1 molal amino acid makes it approximately isotonic.

(8) Albumin stabilized with 0.04 molal acetyltryptophane or mandelate may be heated for 10 hours at $60^{\circ} \mathrm{C}$. and remain more stable than the present albumin. Still higher temperatures and longer times could be achieved by the use of larger amounts and different combinations of stabilizing reagents. It should thus be possible to determine conditions such that the albumin will remain stable, while bacteria and viruses will be destroyed.

(9) The heating of albumin for 10 hours or more at $60^{\circ} \mathrm{C}$. or higher in the final containers 
should render it reasonably safe to eliminate the addition of a mercurial bacteriostatic agent and thus to make available a blood derivative of high osmotic efficiency and low sodium content which can be used in large amounts, not only in shock, but in a variety of other conditions.

\section{BIBLIOGRAPHY}

1. Cohn, E. J., Strong, L. E., Hughes, W. L., Jr., Mulford, D. J., Ashworth, J. N., and Melin, M., Preparation and Properties of Serum and Plasma Proteins. IV. A System for the Separation into Fractions of the Protein and Lipoprotein Components of Biological Tissues and Fluids. To be published.

2. Stokes, J., Jr., and Neefe, J. R., The prevention and attenuation of infectious hepatitis by gamma globulin. J. A. M. A., 1945, 127, 144.

3. Scatchard, G., Batchelder, A. C., and Brown, A., Chemical, clinical, and immunological studies on the products of human plasma fractionation. VI. The osmotic pressure of plasma and of serum albumin. J. Clin. Invest., 1944, 23, 458.

4. Cohn, E. J., Properties and functions of plasma proteins, with a consideration of the methods for their separation and purification. Chem. Rev., 1941, 28, 395.

5. Gram, H. C., Observations on the regulation of osmotic pressure (conductivity, chlorides, freezing point, and proteins of serum). J. Biol. Chem., 1923, 56, 593.

6. Scatchard, G., Gibson, S. T., Woodruff, L. M., Batchelder, A. C., and Brown, A., Chemical, clini$\mathrm{cal}$, and immunological studies on the products of human plasma fractionation. IV. A study of the thermal stability of human serum albumin. J. Clin. Invest., 1944, 23, 445.

7. Janeway, C. A., Gibson, S. T., Woodruff, L. M., Heyl, J. T., Bailey, O. T., and Newhouser, L. R., Chemical, clinical, and immunological studies on the products of human plasma fractionation. VII. Concentrated human serum albumin. J. Clin. Invest., 1944, 23, 465.

8. Thorn, G. W., Armstrong, S. H., Jr., Dickerson, V. C., Woodruff, L. M., and Tyler, F. H., Chemical, clinical, and immunological studies on the products of human plasma fractionation. XXVII. The use of salt-poor concentrated human serum albumin solution in the treatment of chronic Bright's disease. J. Clin. Invest., In press.
9. Thorn, G. W., Armstrong, S. H., Jr., and Dickerson, V. C., Chemical, clinical, and immunological studies on the products of human plasma fractionation. XXVIII. The use of salt-poor concentrated human albumin solution in the treatment of hepatic cirrhosis. To be published.

10. Hutchins, G., and Janeway, C. A., Personal communication.

11. Ballou, G. A., Boyer, P. D., Luck, J. M., and Lum, F. G., Chemical, clinical, and immunological studies on the products of human plasma fractionation. $V$. The influence of non-polar anions on the thermal stability of serum albumin. J. Clin. Invest., 1944, 23, 454.

12. Ballou, G. A., Boyer, P. D., Luck, J. M., and Lum, F. G., The heat coagulation of human serum albumin. J. Biol. Chem., 1944, 153, 589.

13. Cohn, E. J., Blood, blood derivatives, and blood substitutes. Proc. Am. Phil. Soc., 1944, 88, 159, footnote p. 167.

14. Brand, E., Kassell, B., and Saidel, L. J., Chemical, clinical, and immunological studies on the products of human plasma fractionation. III. Amino acid composition of plasma proteins. J. Clin. Invest., 1944, 23, 437.

15. Hegsted, D. M., Hay, A., and Stare, F. J., Chemical, clinical, and immunological studies on the products of human plasma fractionation. XXIV. Studies on the nutritive value of human plasma fractions. J. Clin. Invest., In press.

16. Stare, F. J., and Davidson, C. S., Protein : its role in human nutrition. J. A. M. A., 1945, 127, 985.

17. Thorn, G. W., and Stare, F. J., Protein nutrition in problems of medical interest. J. A. M. A., In press.

18. Hegsted, D. M., McKibben, J. M., and Stare, F. J., The nutritive value of human plasma for the rat. J. Clin. Invest., 1944, 23, 705.

19. du Vigneaud, V., Sealock, R. R., and Van Etten, C., The availability of $d$-tryptophane and its acetyl derivative to the animal body. J. Biol. Chem., 1932, 98, 565.

20. Cohn, E. J., Oncley, J. L., Strong, L. E., Hughes, W. L., Jr., and Armstrong, S. H., Jr., Chemical, clinical, and immunological studies on the products of human plasma fractionation. I. The characteristization of the protein fractions of human plasma. J. Clin. Invest., 1944, 23, 417.

21. Lauffer, M. A., and Price, W. C., Thermal denaturation of tobacco mosaic virus. J. Biol. Chem., 1940, 133, 1.

22. Price, W. C., Thermal inactivation rates of four plant viruses. Arch. f. d. ges. Virusforsch., 1940, 1, 373. 